\title{
Flour Distribution, the Problem and Its Causes, Case of XYZ Company, Indonesia
}

\author{
Agung Putra Pamungkas* and Henry Yuliando \\ Department of Agro-industrial Technology, Faculty of Agricultural Technology \\ Universitas Gadjah Mada, Jl. Flora No.1 Bulaksumur 55281, Indonesia. \\ Email: pamungkas.agungputra@gmail.com*
}

\begin{abstract}
The distribution of wheat flour in Indonesia uses almost all type of marketing channels. Markets of wheat flour involve manufacturers, wholesalers, retailers, and end customers. The distribution of XYZ wheat flour company is direct distribution, from their company to the industry, especially to western and eastern parts of Java Island. It was found that XYZ company has not satisfied with their distribution performance, hence in this study, the problem and its causes was analyzed. Using the criteria of response time, product variety, availability, customer experience, time to market, order visibility and return ability, an in-depth-interview were conducted to several types of distribution channel. The results showed that unsynchronized information and lack of coordination in distribution policies are the most influencing factors that cause inefficiency problem of XYZ product distribution.
\end{abstract}

Keywords: distribution channel, performance, root-cause analysis, wheat flour.

\section{INTRODUCTION}

Wheat is a crop among cereals that are planted in some part of the world and are traded internationally. Most of wheat is consumed in the form of baked goods, mainly bread. It has to be processed into flour before being used for bread production. Wheat is also used as an ingredient in starch production and as a feedstock in ethanol production. The leading countries known for their wheat production are Australia, Canada, EU, Ukraine, United States, and Argentina (USDA, 2015). The world wheat production and consumption are shown in Fig.1.

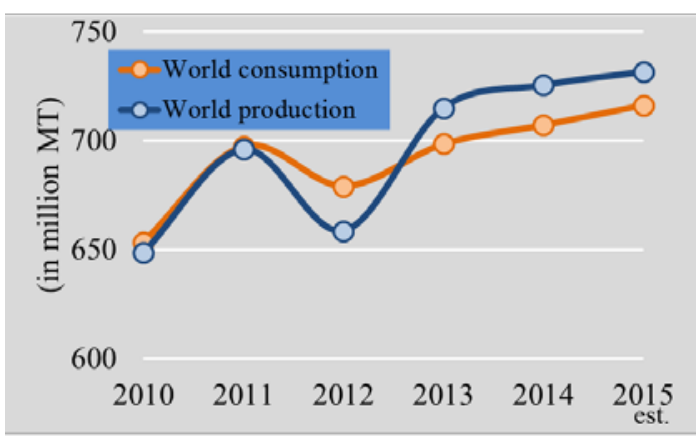

Figure 1 Global wheat production and consumption (USDA, 2015)

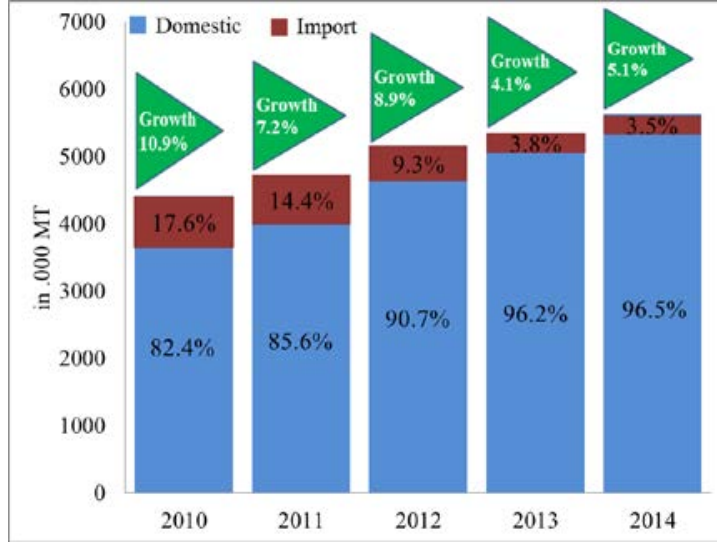

Figure 2 Indonesian wheat flour consumption

(USDA, 2015)

Over the last decade, Indonesia consumes a huge amount of wheat and is the second largest importer country for wheat, flour, and its products (after Egypt). The total of Indonesia import values were increase significantly from 5800 to 7400 Thousand Metric Tons (TMT) or increased 27.6\% during 2010-2014 period (based on USDA data) as shown in Fig.2. The average real expenditure on wheat-related products per household in Indonesia has increased by $26 \%$ as wheat based food products are emerging as new daily staple food in Indonesia (Gonzalo et.al, 2014). Based on Indonesia Statistics Data Bureau, 
household expenditure on flour and its related product has been growing rapidly on the consumption of wheat related products by mediocre segment people. If the growth of wheat consumption is $10 \%$ per year, there has to be more 300 TMT wheat flour or 500 TMT of wheat production per year to cover the consumption of wheat flour that reached 30.2 kg/capita/year on 2014 (Fig.3). However, direct consumption of wheat flour represented only $8.6 \%$ of total milled wheat flour (Asosiasi Produsen Tepung Terigu Indonesia [APTINDO] 2009).

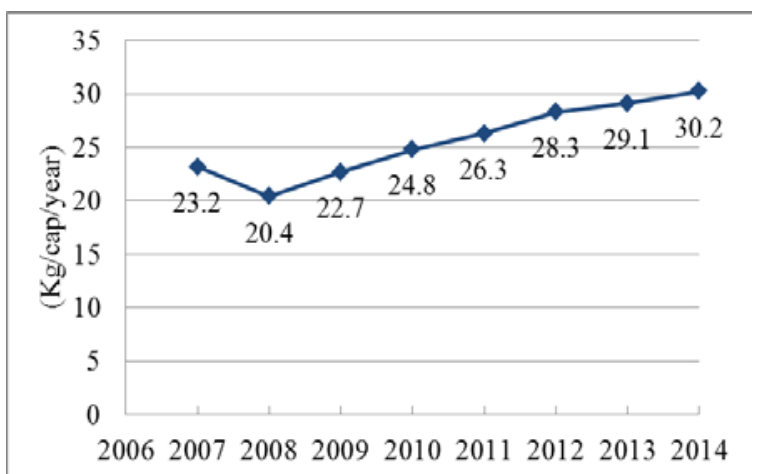

Figure 3 Indonesian wheat equivalents per capita consumption (APTINDO, 2015)

Based on APTINDO (2015), wheat flour market share was dominated by Bogasari (57.3\%), imports (15.5\%), and local producers of wheat flour such as PT Eastern Pearl (10.3\%), PT Sriboga Flour Mill (5.5\%), PT Panganmas Inti Persada (3.2\%), PT Pundi Kencana $(0.4 \%)$, and other local producers (7.8\%). Almost all the wheat flour companies use the whole marketing channels. The market of wheat flour involves manufacturers, wholesalers, retailers, and end-customers in order to supply the flour wherever and whenever needed. The wholesalers as the biggest distributors consist of sub-distributors known as "grosir" and they obtain the wheat flour from the manufacturers, distributor fellows, even importers (BPS, 2014).

Although Indonesia's wheat output has been steadily increasing, the production process still faces many constraints: limited arable land and competition between grains and oilseeds for that land; yields in developed countries are believed to be close to their biological potential and; farmers experience problems with access to capital and support infrastructure (FAO, 2009), and distribution problems. One of the purposes of this study is to explore the problems happened during the distribution of wheat flour in Indonesia. Indonesia as an archipelago country (with over 17500 islands, 6000 of which are inhabited, but around 1000 are permanently settled) and its various social- conditions (over 245 million people estimated to be living in Indonesia) becoming the main reason of those situations. To maintain the wheat flour supply that meets the total demand of Indonesian people, it is very important to deliberate and analyze the best distribution and market channel of its products.

Distribution pattern shows the supply chain of a product from producer to consumer. Good supply chains will create a product delivery to consumer with lowest cost, and able to give all the payment cost from consumer to all vendors included in the process. Distribution pattern of wheat flour was assumed to have many troubles because of some factors such as the improper actions of market channels (producers, wholesalers, and retailers), wheat flour quality, higher disparity of local prices than import prices of wheat flour, business margin, etc. In 2015, there were 31 flour mill companies, members of APTINDO in which the biggest Indonesia wheat flour producers. Therefore, the milling capacity of APTINDO could be considered as national capacity. APTINDO reached 11.2 million metric tons (MMT) wheat per year, meant that national production of wheat flour was 5.43 MMT on 2014 (APTINDO, 2015).

One of the biggest Indonesian wheat flour producers, XYZ company, faces several problems related to the distribution of their products. This study aimed to analyze and evaluate the distribution performance of wheat flour industry in Indonesia by taking a wheat flour factory as a case study.

\section{MATERIAL AND METHODS}

\section{Research object}

$\mathrm{XYZ}$ company is one of the biggest milling company located in Java, and running the production of raw wheat flour. The specialty of their product is the customization; therefore XYZ company would produce the wheat flour with specifications demanded by 
the consumers. Figure 4 shows the product distribution of XYZ company, which is mainly concentrated in Java.

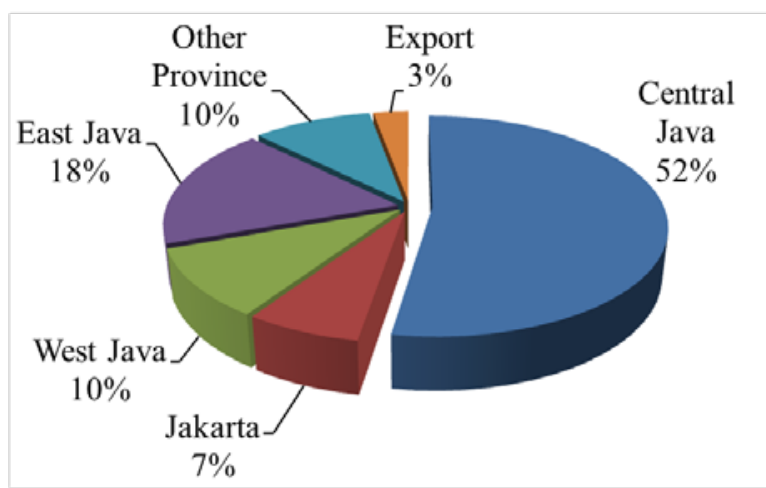

Figure 4. The distribution of XYZ flour company

The research objects in this study are XYZ company, their distributors, wholesalers, and retailers in Jakarta, Bogor, Semarang, Solo and Yogyakarta. The specification of chosen object of this study is devoted only to distributors, wholesalers, and retailers who have formed a partnership with XYZ company for more than one year.

The data source of this research was obtained from the primary data in the form of a company profile, a list of distributors, wholesalers, and retailers in Jakarta, Bogor, Semarang, Solo and Yogyakarta, and interviews conducted directly by researchers in the field.

The questionnaire was addressed to the persons in charge of company's distribution channel. The questionnaire consists of questions and choice of answers was provided to be filled freely by the respondent.

\section{RESULTS AND DISCUSSION}

\subsection{Process Flow Diagram}

XYZ company orders raw materials regularly every year and the suppliers sent 3 to 4 times a month. The delivery of raw materials is carried by sea ship arrive on each week. The ships come and stay for 5 to 6 days at the port for quality control process, to checks and records the ordered raw materials conditions.

The next step is processing wheat seeds into flour. First step is preparation that consists of cleaning process, humidifying (dampening), and conditioning the wheat seeds. Once the preparation is completed, it goes to the grinding process that includes the process of breaking, reduction, sizing, and tailings. Next stage is mixing to produce the flour into several quality standards. Processing time for quality control takes three days, while the customized products with certain qualities require seven days to produce. The final stage is packaging. Prior packaging, the products are checked and recorded. When it passes the quality control it will be sent to the distributor. The delivery is done on daily basis either directly to final consumers (large industry and SMEs) or to dealers (distributors, wholesalers, and retailers). Production capacity of XYZ company reached 1.25 million kilograms for 1 $\mathrm{kg}$ wheat packing, 1.118 million kilograms for 25 kilograms packing, and 1.112 million kilograms for the jumbo size (75 kilograms packing).

\subsection{Performance evaluation of the distribution channels}

Total respondents in this study were 19 respondents that consist of five distributors, ten wholesalers, and four retailers, located in the region of Jakarta, Bogor, Semarang, Solo and Yogyakarta. Respondents are those who sell the products of XYZ company and they rely on well-known brand of the products for its competitive price and quality. The interview results summarize below.

\section{Response Time}

The wholesalers and retailers do not significantly different concerning to the response time. Product delivery time from distributors to wholesalers and wholesalers to retailers took 1-2 days, but if there was long queue at the factory, the delivery will be delayed up to two weeks. In this occasion, the company would help to find other stock that available other traders/retailers to cover the shortfalls.

\section{Product Variety}

XYZ company produced 20 product varieties . However, the products availability often out of stock and caused more problems. Most of the respondents sell 5 to 15 variations of the product, whereas some of them sell 1 to 2 variations out of 20 product varieties. Respondents only sell the products that mostly consumed by their customers. 


\section{Product Availability}

Retailers stock of wheat flour is one sack per week, while wholesalers keep 300 to 600 sacks per week. When the stocks decreased, they reorder the wheat flour immediately. It caused the unavailability of the wheat flour in some period of time.

The peak demand of the products occurs during Ramadhan (fasting month). In this month, some respondents also reduced their stock since most of their customers are sellers of bread, noodles, and fried food that were stop their activity during Ramadhan. In the end of Ramadhan, some respondents increase their stock from 100 to 200 packs due to the off season of the factory - XYZ company. However, there were also respondents who did not experience any difference in the amount of stock since they have regular customers.

\section{Customer Experience}

Respondents ordering the products by phone, requesting the amount and type of products to be delivered. The lead time is about one to three days. A wholesaler does not make a phone reservation but immediately come to other wholesalers or distributors to reduce the lead time.

\section{Time to Market}

The respondents are not willing to sell a new product before the product is being promoted to avoid the marketing risk. In other hand, the distributors will sell all the company's new products.

\section{Returnability}

In some certain time, the respondents could claim the perished products to the factory and the company will give the compensations to the respondents. If the respondents exceed the period then it cannot be returned.

\section{CONCLUSION}

This study revealed that unsynchronized information and lack of coordination as the most influencing factors causing problem in flour distribution of XYZ company. Product delivery time varied from 1 to 2 days, but often to delay. With many product varieties, out of stock often occurred and causes unsatisfactory. Order has not been fully adapted with sufficient scheduling, and distributors tend not to support the company in introducing the new variety.

Therefore, it is necessary for company to implement more effective coordination strategies with distributor in term of market survey, vendor managed inventory, and risk sharing.

\section{REFERENCES}

APTINDO. 2009. Pangsa Pasar Industri Tepung Terigu Tahun 2009. (http://www.aptindo.or.id) Accessed on October 28, 2015.

BPS. 2014. Distribusi Perdagangan Komoditi Tepung Terigu Indonesia 2014. Jakarta: BPS.

FAO. 2009. Agribusiness Handbook: Wheat Flour. Rome, Italy: FAO.

Gonzalo J. Varela and Kiyoshi Taniguchi, 2014. Asymmetric Price Transmission in Indonesia's Wheat Flour Market. ADB economics working paper series. ADB.

Media Data Riset. 2013. Persaingan Bisnis Tepung Terigu Paska Bea Masuk Tambahan dan Safeguard, 2013. (http://mediadata.co.id) Accessed on March 20, 2015.

USDA. 2015. Grain: World Markets and Trade. Foreign Agriculture Services: USDA. USA. 